\title{
Ellipsis
}

2021

\section{Rhododendrons: A Compound Lilibonelle}

Nancy E. Wright

University of New Orleans

Follow this and additional works at: https://scholarworks.uno.edu/ellipsis

\section{Recommended Citation}

Wright, Nancy E. (2021) "Rhododendrons: A Compound Lilibonelle," Ellipsis: Vol. 46 , Article 15.

DOI: https://doi.org/10.46428/ejail.46.15

Available at: https://scholarworks.uno.edu/ellipsis/vol46/iss1/15

This Poetry is brought to you for free and open access by the Department of English and Foreign Languages at ScholarWorks@UNO. It has been accepted for inclusion in Ellipsis by an authorized editor of ScholarWorks@UNO. For more information, please contact scholarworks@uno.edu. 


\section{Rhododendrons: A Compound Lilibonelle By Nancy E. Wright}

I.

I am a small country

On an infinite journey,

Tucked between dynasties,

Enfolding scarlet rhododendrons

Cascading down forested mountains,

Their currents transcending current time.

On an infinite journey,

Stretching backward and forward,

Like a tiger reclining across centuries,

Reaching as far as a dragon's thunder,

Lasting long like the fire of chili peppers

On the lips of my storytellers.

Tucked between dynasties

That trade with and invade me.

I too have been kingdom and trader, defender, invader.

With skirmished frontiers, I pulled myself apart,

Then wiser, traded water for oil.

My giant neighbor needed energy, and I needed fuel.

Enfolding scarlet rhododendrons

Surrounding glacier-fed red rice paddies,

Overlooking asparagus gardens and orchards of apples,

Earth, sunshine, and water render nourishment and growth:

Modern tradition, traditionally modern,

Mysterious happiness in a peaceful land.

Cascading down forested mountains

Are the narratives of my life,

The seeds, the buds, the blossoms cradling seeds

That must fall into rich earth to grow tall.

Falling ahead and advancing back--

This is what I call happiness.

Their currents transcending current time,

These rhododendrons are eternal,

Scarlet emblems of my changeless heart, Embraced by deciduous and evergreen,

More growth than progress, both falling and remaining, As lines reappear in the newness of eternity. 
I am a small country

On an infinite journey,

Tucked between dynasties,

Enfolding scarlet rhododendrons

Cascading down forested mountains,

Their currents transcending current time.

On an infinite journey,

Devotees make their pilgrimage to Sikkim's holy lake,

Named after Guru Rinpoche, who on the

Back of a tiger, brought Buddhism to me, Druk Yul.

The hydraulic excavator bites with the teeth of modernity;

Will the newly paved asphalt blunt the teeth of the tiger?

Tucked between dynasties,

I sequester my being.

Yet with peripheral eye, I watch for possibilities--

To educate engineers, to rocket to the moon,

To launch hydropower for revenue, with migrant labor to build,

To import food to fill bellies when the chili peppers fade.

Enfolding scarlet rhododendrons

Released to lift asparagus, butter tea,

And apples to certain tongues torpid with monotony,

Eyes still cherish these rhododendrons,

And hearts are still grateful for gardens, orchards, and red rice,

But some taste buds crave cake and espresso after datshi cheese and chili peppers.

Cascading down forested mountains

Are new narratives tumbling on the roads

Yet unfinished-seeds of narratives that thrive on asphalt,

For they yield not fruit nor blossoms, but grit and friction.

They exfoliate contentment like dry, useless skin.

Are these the narratives of real happiness?

Their currents transcending current time,

This happiness has harrowed the farmer's field.

But did the farmer feel happy before? Or was happiness a hoax

Clutched in subsistence and the empty gaze of the yak?

Shall I forget the dragon and tiger, as I am reminded to build the roads?

After all, visitors do not have time to sink in the dirt of narrow switchbacks.

They need smooth pavements to transport the great happiness they have gleaned. 
I am a small country

On an infinite journey,

Tucked between dynasties,

Enfolding scarlet rhododendrons

Cascading down forested mountains,

Their currents transcending current time.

On an infinite journey,

Back from the pilgrimage,

Entering Thimphu, the visitors purchase precious tokens,

Authentically preserved by India or Nepal.

Locals saunter through the streets with no traffic lights to interrupt

Their frolic to the disco, the drayang, the bar.

Tucked between dynasties,

Sequestered, almost suffocated,

Richly impoverished with the poorest of wealth,

My skirmished frontiers tear my giant, shrinking world.

The big dams will shake the Himalayas and displace indigenous people,

But building the small hydropower plants may not be worth the dam price.

Enfolding scarlet rhododendrons

Are the hands of teacher, yak herder,

Banker, subsistence farmer, urban government worker.

The red rice, apples, and asparagus still grow in season,

But the endangered wild boar and monkey have invaded the farm.

May I take a loan for prosperity with rhododendron collateral?

Cascading down forested mountains

Are the narratives of old growth trees,

Never needing replacement, for they were never felled.

Is anyone's future found in destruction?

I see the twig's shadow in a ngultrum paper note;

To hold the note, at least one hand must release the rhododendrons.

Their currents transcending current time,

These rhododendrons ensure my eternity-

Scarlet emblems of relentless circumspection.

Gross National Happiness is a switchback journey not a paved condition.

With one hand on the ngultrum and one on the rhododendrons,

I must journey with currency to transcend current time. 